\title{
Biodiversity of Dickeya spp. Isolated from Potato Plants and Water Sources in Temperate Climate
}

\author{
Marta Potrykus, Malgorzata Golanowska, Wojciech Sledz, Sabina Zoledowska, and Agata Motyka, Laboratory of Plant Protection and \\ Biotechnology, Intercollegiate Faculty of Biotechnology of University of Gdansk and Medical University of Gdansk, Kladki 24, 80-822 \\ Gdansk, Poland; Anna Kolodziejska and Janina Butrymowicz, The Central Laboratory of the State Plant Health and Seed Inspection Service, \\ Zwirki i Wigury 73 87-100 Torun, Poland; and Ewa Lojkowska, Laboratory of Plant Protection and Biotechnology, Intercollegiate Faculty of \\ Biotechnology of University of Gdansk and Medical University of Gdansk
}

\begin{abstract}
Potrykus, M., Golanowska, M., Sledz, W., Zoledowska, S., Motyka, A., Kolodziejska, A., Butrymowicz, J., and Lojkowska, E. 2016. Biodiversity of Dickeya spp. isolated from potato plants and water sources in temperate climate. Plant Dis. 100:408-417.

Bacteria from the genera Dickeya (formerly Erwinia chrysanthemi) and Pectobacterium (formerly E. carotovora) are the agents of blackleg and soft rot on many important crops. In 2005, Dickeya solani was isolated for the first time in Poland from a symptomatic potato plant. To establish the presence and diversity of Dickeya spp. in Poland, we surveyed potato fields and water sources, including surface waters near potato fields and water from potato-processing facilities and sewage plants. Only

D. dianthicola and D. solani were isolated from symptomatic potato, and only $D$. zeae and $D$. chrysanthemi were isolated from water sources. The Dickeya spp. isolated from potato formed a relatively homogenous group, while those from water sources were more diverse. To our knowledge, this is the first comprehensive characterization of Dickeya spp. isolated during several years from regions with a temperate climate in Central Europe.
\end{abstract}

Bacteria belonging to the genera Dickeya (formerly Erwinia chrysanthemi) and Pectobacterium (formerly E. carotovora) are pathogens of many economically important crops. These species have been included among the 10 most important bacterial plant pathogens based on their economic or scientific impact (Mansfield et al. 2012). The genus Dickeya has gone through major classification changes since Samson et al. (2005) assigned E. chrysanthemi to a novel genus, Dickeya, and divided it into six species: Dickeya chrysanthemi, D. dadantii, $D$. dianthicola, $D$. dieffenbachiae, $D$ paradisiaca, and $D$. zeae. More recently, $D$. dieffenbachiae was renamed $D$. dadantii subsp. dieffenbachiae (Brady et al. 2012) and two new species were described: D. aquatica and D. solani (Parkinson et al. 2014; van der Wolf et al. 2014). Currently, the genus Dickeya comprises seven genomospecies, but several reports suggest that new species of Dickeya may be described in the future (Palacio-Bielsa et al. 2010; Suharjo et al. 2014).

The pathogenic species of Dickeya and Pectobacterium are responsible for blackleg and soft rot. Blackleg symptoms include stem rot that can spread from the rotting seed tubers. It leads to leaf wilt, decreased growth, collapse of the plant, or even a complete lack of plant emergence (Pérombelon 2002). Soft rot symptoms include the odorless maceration of plant tissue, and the disease can develop both in the field and during storage.

Corresponding author: E. Lojkowska; E-mail: ewa.lojkowska@biotech.ug.edu.pl

GenBank accession numbers for new gene sequences reported here are KR135078 to KR135112. The D. solani strains IFB0099 (LMG28824), IFB0158 (LMG28826), and IFB0168 (LMG28827); D. dianthicola strains IFB0157 (LMG28825) and IFB0485 (LMG28834); D. zeae strains IFB0189 (LMG28828), IFB0280 (LMG28829), IFB0329 (LMG28832), and IFB0334 (LMG28833); and D. chrysanthemi strains IFB0289 (LMG28830) and IFB0320 (LMG28831) were deposited in BCCM/LMG Belgian Collection of Microorganisms.

*The $\boldsymbol{e}$-Xtra logo stands for "electronic extra" and indicates that one supplementary figure is published online.

Accepted for publication 7 August 2015.

http://dx.doi.org/10.1094/PDIS-04-15-0439-RE

(C) 2016 The American Phytopathological Society
Dickeya spp. are pathogens of both monocotyledons and dicotyledons (Ma et al. 2007). Dickeya spp. cause symptoms only under favorable conditions but can survive in plant tissue for long periods (Pérombelon 2002). In Europe, Dickeya spp. are pathogens of a wide range of hosts, including potato, ornamental plants, and herbs (Toth et al. 2011). Several countries have undertaken preventive measures to reduce the spread of $D$. solani. For instance, Scotland introduced a "zero-tolerance" policy for Dickeya spp. in potato production systems in 2010 (Elphinstone and Toth 2007), while Jamaica has listed Dickeya spp. as a quarantine pest (http://www.moa.gov. $\mathrm{jm} /$ PlantHealth/index.php) and prohibited import of seed potato from The Netherlands and Belgium. Moreover, Dickeya spp. have become a quarantine pest in Israel (Tsror (Lahkim) et al. 2012). In Asia, the most prevalent species of Dickeya seems to be D. zeae, which has been reported to cause rice foot rot, banana soft rot, and bacterial stalk rot of maize (Myung et al. 2010; Pu et al. 2012; Zhang et al. 2014). D. solani causes economic loss in Israel. In this country, Dickeya spp. can spread and multiply rapidly because temperatures are high and fields are irrigated (Tsror (Lahkim) et al. 2009).

D. solani has been detected in potato plants in several European countries (Sarris et al. 2011; Sławiak et al. 2009a; Toth et al. 2011, van der Wolf et al. 2014) but the existence of Dickeya spp. (and especially $D$. solani) in waterways and other water sources has not been extensively studied. Most species found in water samples were identified as $D$. zeae but a few were identified as $D$. aquatica, D. chrysanthemi, D. dianthicola, D. solani, or an unidentified clade of DUC-2 (MK-7), (Laurila et al. 2008, 2010; Palacio-Bielsa et al. 2010; Parkinson et al. 2009, 2014; Pritchard et al. 2013b). Researchers have yet to determine whether Dickeya spp. can spread through waterways from country to country. To date, $D$. aquatica strains have been isolated only from the waterways of Scotland and Finland (Parkinson et al. 2014).

In 2005, D. solani was isolated for the first time in Poland; the bacterium was isolated from a symptomatic potato plant originating from a potato seed plantation (Sławiak et al. 2009a). This detection of D. solani and the general lack of information concerning Dickeya spp. in Poland motivated us to conduct a detailed ecological survey for Dickeya spp. in potato plantations and waterways and other water sources in Poland.

Here, we report the results of a 4-year survey of potato plantations and water sources for Dickeya spp. The Dickeya spp. isolated from both plant and water samples were subjected to molecular 
Table 1. Reference Dickeya strains used in this study, including type strains and strains previously isolated from water in various European countries other than Poland

\begin{tabular}{|c|c|c|c|c|c|c|c|c|}
\hline Number & Species & $\begin{array}{c}\text { IFB collection } \\
\text { number }\end{array}$ & $\begin{array}{c}\text { Other collection } \\
\text { numbers }\end{array}$ & $\begin{array}{c}\text { Country, year } \\
\text { of isolation }\end{array}$ & Origin & $\begin{array}{c}\text { Tuber } \\
\text { maceration } \\
\text { assay }^{\mathrm{a}}\end{array}$ & $\begin{array}{c}\text { PFGE } \\
\text { profile }^{b}\end{array}$ & Reference $^{c}$ \\
\hline 1 & Dickeya aquatica & IFB0153 & Dw0431 & Finland & Water & $\ldots$ & 29 & Laurila et al. 2008 \\
\hline 2 & D. aquatica & IFB0154 & Dw0440 & Finland, 2005 & Water & $\ldots$ & 30 & $\begin{array}{l}\text { Laurila et al. 2008, } \\
\text { Parkinson et al. } 2014\end{array}$ \\
\hline 3 & D. aquatica & IFB0155 & Dw054 & Finland, 2005 & Water & $\ldots$ & 31 & $\begin{array}{l}\text { Laurila et al. 2008, } \\
\text { Parkinson et al. } 2014\end{array}$ \\
\hline 4 & D. aquatica & IFB0156 & Dw0512 & Finland, 2005 & Water & & 32 & Laurila et al. 2008 \\
\hline 5 & $\begin{array}{l}\text { D. chrysanthemi } \\
\text { pv. chrysanthemi } \mathrm{T}\end{array}$ & IFB0055 & $\begin{array}{l}\mathrm{NCPPB} 402 \mathrm{~T}^{\mathrm{T}}, \\
\text { CFBP2048 }^{\mathrm{T}} \text {, } \\
\text { IPO2118 }\end{array}$ & $\begin{array}{l}\text { United States, } \\
1958\end{array}$ & $\begin{array}{l}\text { Chrysanthemum } \\
\text { morifolium }\end{array}$ & $0.14( \pm 0.09)$ & 20 & Samson et al. 2005 \\
\hline 6 & D. dadantii & IFB0003 & - & - & - & $\ldots$ & 51 & IFB \\
\hline 7 & D. dadantii ${ }^{\mathrm{T}}$ & IFB0010 & $\begin{array}{l}{\text { NCPPB } 898^{\mathrm{T}}}, \\
\text { CFBP1269 }^{\mathrm{T}}, \\
\text { IPO2120, } \\
\text { SCRI1269 }\end{array}$ & Comoros, 1960 & $\begin{array}{l}\text { Pelargonium } \\
\text { capitatum }\end{array}$ & $1.24( \pm 0.23)$ & 17 & Samson et al. 2005 \\
\hline 8 & D. dadantii & IFB0016 & 3937 & France & Saintpaulia & $\ldots$ & 18 & Kotoujansky et al. 1982 \\
\hline 9 & $\begin{array}{l}\text { D. dadantii subsp. } \\
\text { dieffenbachiae }^{\mathrm{T}}\end{array}$ & IFB0113 & $\begin{array}{l}{\text { NCPPB } 29766^{\mathrm{T}}} \\
\text { CFBP2051 } \\
\text { IPO2125 }\end{array}$ & $\begin{array}{l}\text { United States, } \\
1957\end{array}$ & $\begin{array}{l}\text { Dieffenbachia } \\
\text { spp. }\end{array}$ & $1( \pm 0.23)$ & 24 & Samson et al. 2005 \\
\hline 10 & D. dianthicola ${ }^{\mathrm{T}}$ & IFB0103 & $\begin{array}{l}{\text { NCPPB } 453^{\mathrm{T}}}, \\
\text { CFBP1200 }^{\mathrm{T}}, \\
\text { IPO2114, } \\
\text { SCRI4073 }\end{array}$ & $\begin{array}{l}\text { United Kingdom, } \\
1956\end{array}$ & $\begin{array}{l}\text { Dianthus } \\
\text { caryophyllus }\end{array}$ & $1.6( \pm 0.0 .53)$ & 2 & Samson et al. 2005 \\
\hline 11 & D. dianthicola & IFB0188 & IPO1747 & Netherlands, 1992 & $\begin{array}{l}\text { Solanum } \\
\text { tuberosum }\end{array}$ & $\ldots$ & 2 & PRI, J. M. van der Wolf \\
\hline 12 & D. paradisiaca $^{\mathrm{T}}$ & IFB0117 & $\begin{array}{l}\text { NCPPB2511 }{ }^{\mathrm{T}}, \\
\text { CFBP4178 } \\
\text { IPO2129 }\end{array}$ & Colombia, 1970 & $\begin{array}{l}\text { Musa } \\
\quad \text { paradisiaca }\end{array}$ & $1.19( \pm 0.38)$ & 15 & Samson et al. 2005 \\
\hline 13 & D. solani ${ }^{\mathrm{T}}$ & IFB0123 & $\begin{array}{l}\text { IPO2222 } \\
\quad \text { NCPPB } 4479^{\mathrm{T}}\end{array}$ & $\begin{array}{l}\text { Netherlands, } \\
2007\end{array}$ & S. tuberosum & $3.5( \pm 0.54)$ & 1 & van der Wolf et al. 2014 \\
\hline 14 & D. solani & IFB0148 & River 2-1 & Scotland & Water & $\ldots$ & 1 & SASA, G. Saddler \\
\hline 15 & D. solani & IFB0272 & MK16, DUC-1 & Scotland & Water & $\ldots$ & 1 & Pritchard et al. 2013a,c \\
\hline 16 & D. zeae & IFB0031 & IPO946 & Netherlands & S. tuberosum & $\ldots$ & 19 & PRI, J. M. van der Wolf \\
\hline 17 & D. zeae & IFB0067 & IPO824 & Israel & Water & $\ldots$ & 21 & PRI, J. M. van der Wolf \\
\hline 18 & D. zeae & IFB0087 & IPO647 & Australia & S. tuberosum & $\ldots$ & 22 & Samson et al. 2005 \\
\hline 19 & D. zeae & IFB0110 & $\begin{array}{l}\text { IPO2121, } \\
\text { NCPPB1121, } \\
\text { CFBP1278 }\end{array}$ & Malaysia 1961 & $\begin{array}{l}\text { Ananas } \\
\text { comosus }\end{array}$ & $1.13( \pm 0.35)$ & 23 & Samson et al. 2005 \\
\hline 20 & $\begin{array}{l}\text { D. zeae } e^{\mathrm{T}}, \\
\text { phylotype II }\end{array}$ & IFB0119 & $\begin{array}{l}\text { IPO2131, } \\
\text { NCPPB2538 } \\
\text { CFBP2052 }^{\mathrm{T}}\end{array}$ & $\begin{array}{l}\text { United States, } \\
1970\end{array}$ & Zea mays & $0.59( \pm 0.2)$ & 25 & Samson et al. 2005 \\
\hline 21 & D. zeae & IFB0120 & $\begin{array}{l}\text { IPO2132, } \\
\text { NCPPB2339, } \\
\text { CFBP4176 }\end{array}$ & $\begin{array}{l}\text { United States, } \\
1970\end{array}$ & C. morifolium & $\ldots$ & 15 & Samson et al. 2005 \\
\hline 22 & D. zeae & IFB0121 & $\begin{array}{l}\text { IPO2133, } \\
\text { CFBP6466 }\end{array}$ & Martinique, 1991 & A. comosus & $\ldots$ & 26 & Samson et al. 2005 \\
\hline 23 & D. zeae & IFB0138 & $\begin{array}{l}\text { IPO3329, } \\
\text { NCPPB3531 }\end{array}$ & Australia & S. tuberosum & $\ldots$ & 16 & van der Wolf et al. 2014 \\
\hline 24 & D. zeae & IFB0216 & IPO650 & Australia, 1980 & S. tuberosum & $\ldots$ & 33 & Parkinson et al. 2009 \\
\hline 25 & D. zeae & IFB0217 & IPO651 & Australia, 1980 & S. tuberosum & $\ldots$ & 16 & Parkinson et al. 2009 \\
\hline 26 & D. zeae & IFB0218 & RW117 & England & Water & $\ldots$ & 34 & FERA, J. Elphinstone \\
\hline 27 & D. zeae & IFB0219 & RW157 & England & Water & $\ldots$ & 35 & FERA, J. Elphinstone \\
\hline 28 & D. zeae & IFB0220 & $\begin{array}{l}\text { RW192, } \\
\text { P7246, } \\
\text { IPO3495 }\end{array}$ & England & Water & $\ldots$ & 35 & $\begin{array}{l}\text { FERA, J. Elphinstone } \\
\text { Pritchard et al. 2013b }\end{array}$ \\
\hline 29 & Dickeya sp. & IFB0147 & River1-1 & Scotland & Water & $\ldots$ & 27 & SASA, G. Saddler \\
\hline 30 & Dickeya sp. & IFB0149 & River3-1 & Scotland & Water & $\ldots$ & 28 & SASA, G. Saddler \\
\hline 31 & Dickeya sp. & IFB0275 & MK7, DUC-2 & Scotland & Water & $\ldots$ & 27 & $\begin{array}{l}\text { Pritchard et al. 2013b } \\
\text { SASA, G. Saddler }\end{array}$ \\
\hline 32 & Dickeya sp. & IFB0277 & CITA A-3 & Spain, 2005 & Water & $\ldots$ & 36 & $\begin{array}{l}\text { Palacio-Bielsa et al. } \\
2010\end{array}$ \\
\hline
\end{tabular}

\footnotetext{
a Values are the means \pm standard error $(n=6)$ of the fresh mass (grams) of macerated tissue per tuber in the potato maceration assay; $\ldots$ indicates that the assay was not performed for this isolate.

b Numbers indicate pulse-field gel electrophoresis (PFGE) profiles obtained for the reference strains and isolates from water and potato plants isolated in Poland and other European countries.

${ }^{c}$ IFB $=$ the collection of Intercollegiate Faculty of Biotechnology University of Gdansk and Medical University of Gdansk, Gdansk, Poland; PRI = the collection of Plant Research International, Wageningen, The Netherlands; FERA = the collection of Fera Science Ltd., York, United Kingdom; and SASA = the collection of Science and Advice for Scottish Agriculture, Edinburgh, United Kingdom.
} 
characterization. Moreover, the maceration ability of Dickeya isolates was determined on potato tubers. To our knowledge, this is the first long-term study of Dickeya spp. in potato fields and water sources in the temperate region of Central Europe.

\section{Materials and Methods}

Bacterial strains, media, and culture conditions. Bacterial strains obtained from international collections are listed in Table 1, while strains isolated and characterized during the current research are listed in Table 2. All strains were grown at $28^{\circ} \mathrm{C}$ on crystal violet pectate (CVP) medium (Hyman et al. 2001), Luria broth agar (LA), or in Luria broth Sambrook et al. 2000) for 24 to $48 \mathrm{~h}$, unless otherwise stated. In liquid cultures, bacteria were grown with agitation (200 rpm; INFORS AGCH-4103).

Collection of symptomatic potato samples. Dickeya spp. in potato fields in Poland were assessed in the growing seasons of 2009, 2010, 2011, and 2013. During these years, we obtained 768 samples of either symptomatic potato stems $(n=546)$ or tubers $(n=222)$. In 27 cases, both potato stems and tubers were tested for pectinolytic Dickeya spp. The majority $(n=691)$ of symptomatic potato samples was obtained by Regional (Voivodeship) Inspectorates of the Main Inspectorate of Plant Health and Seed Inspection (MIPH\&SI), Warsaw, Poland. Samples were collected during standard inspections of potato seed plantations by MIPH\&SI inspectors each year between May and December; $24.5 \%$ of the samples were collected in June,
$56.2 \%$ in July, and $7.7 \%$ in August. Potato tubers obtained later than September were from potato storage facilities. Another 77 samples were acquired from the following institutions: Plant Breeding and Acclimatization Institute-Potato Breeding Zamarte, Jadwisin and Młochów Research Center; Plant Breeding in Szyldak Sp. z o. o.; Pomeranian-Mazurian Potato Breeding in Strzekęcin Sp. z o. o.; and Wroclaw University of Environmental and Life Sciences, Wroclaw, Poland. The samples were collected from 98 cultivars but $43 \%$ of the samples were from the following seven cultivars: 'Denar' (8.7\%), 'Vineta' (7.8\%), 'Irga' (7.3\%), 'Satina' (7.0\%), 'Lord' (5.3\%), 'Innovator' $(3.4 \%)$, and 'Bryza' (3.3\%). For $4.8 \%$ of the potato samples, no information was obtained about potato cultivar. After collection, each sample was placed in a plastic bag, tightly sealed, and sent (along with completed questionnaires) in a padded envelope to our laboratory. Most samples reached our laboratory within 2 days. The questionnaire included date and place of collection, potato cultivar, weather conditions, and the kind and amount of fertilizers used in the field.

Collection of water samples. In total, 7,902 water samples were obtained from the Central Laboratory (Torun, Poland) of MIPH\&SI in 2010, 2011, 2012, and 2013. The samples were collected by the inspectors as part of the routine inspection for Ralstonia solanacearum, as described in EU Commission Directive 2006/63/CE. Samples were collected twice each year: in June to July and in August to September.

Table 2. Dickeya spp. isolated from potato and water samples in Poland

\begin{tabular}{|c|c|c|c|c|c|c|c|}
\hline Isolate $^{\mathbf{a}}$ & Species & IFB numberb & Year of isolation & Potato cultivar ${ }^{\mathrm{c}}$ & Plant part ${ }^{\mathrm{c}}$ & Potato maceration assay ${ }^{d}$ & PFGE profile ${ }^{e}$ \\
\hline \multicolumn{8}{|l|}{ Potato } \\
\hline 1 & D. dianthicola & IFB0157 & 2009 & Lord & Stem & $0.94( \pm 0.32)$ & 2 \\
\hline 2 & D. dianthicola & IFB0485 & 2013 & Igor & Stem & $0.44( \pm 0.13)$ & 3 \\
\hline 3 & D. dianthicola & IFB0486 & 2013 & Bellarosa & Tuber & $1.21( \pm 0.3)$ & 3 \\
\hline 4 & D. solani & IFB0099 & 2005 & Santa & Stem & $3.13( \pm 0.26)$ & 1 \\
\hline 5 & D. solani & IFB0158 & 2009 & Kuras & Stem & $3.19( \pm 0.71)$ & 1 \\
\hline 6 & D. solani & IFB0167 & 2009 & Fresco & Stem & $2.09( \pm 0.51)$ & 1 \\
\hline 7 & D. solani & IFB0168 & 2009 & Fresco & Stem & $2.19( \pm 0.14)$ & 1 \\
\hline 8 & D. solani & IFB0169 & 2009 & Innovator & Stem & $2.94( \pm 0.3)$ & 1 \\
\hline 9 & D. solani & IFB0203 & 2010 & Amora & Stem & $2.32( \pm 0.32)$ & 1 \\
\hline 10 & D. solani & IFB0204 & 2010 & Jelly & Stem & $2.81( \pm 0.56)$ & 1 \\
\hline 11 & D. solani & IFB0214 & 2010 & Kuras & Stem & $3.85( \pm 0.36)$ & 1 \\
\hline 12 & D. solani & IFB0296 & 2011 & $\ldots$ & Stem & $2.69( \pm 0.53)$ & 1 \\
\hline 13 & D. solani & IFB0300 & 2011 & Wiarus & Stem & $2.93( \pm 0.4)$ & 1 \\
\hline 14 & D. solani & IFB0304 & 2011 & Verne & Stem & $3.01( \pm 0.49)$ & 1 \\
\hline 15 & D. solani & IFB0309 & 2011 & Berber & Stem & $3.13( \pm 0.54)$ & 1 \\
\hline 16 & D. solani & IFB0311 & 2011 & Innovator & Stem & $3.85( \pm 0.7)$ & 1 \\
\hline 17 & D. solani & IFB0313 & 2011 & Innovator & Stem & $3.08( \pm 0.43)$ & 1 \\
\hline 18 & D. solani & IFB0318 & 2011 & Innovator & Stem & $\ldots$ & 1 \\
\hline 19 & D. solani & IFB0458 & 2013 & Bellarosa & Stem & $3.27( \pm 0.35)$ & 1 \\
\hline 20 & D. solani & IFB0487 & 2013 & Vineta & Stem & $2.87( \pm 0.42)$ & 1 \\
\hline \multicolumn{8}{|l|}{ Water } \\
\hline 21 & D. chrysanthemi & IFB0283 & 2011 & $\mathrm{Na}$ & $\mathrm{Na}$ & $\ldots$ & 39 \\
\hline 22 & D. chrysanthemi & IFB0284 & 2011 & $\mathrm{Na}$ & $\mathrm{Na}$ & $\ldots$ & 40 \\
\hline 23 & D. chrysanthemi & IFB0287 & 2011 & $\mathrm{Na}$ & $\mathrm{Na}$ & $\ldots$ & 4 \\
\hline 24 & D. chrysanthemi & IFB0288 & 2011 & $\mathrm{Na}$ & $\mathrm{Na}$ & $\ldots$ & 4 \\
\hline 25 & D. chrysanthemi & IFB0289 & 2011 & $\mathrm{Na}$ & $\mathrm{Na}$ & $\ldots$ & 6 \\
\hline 26 & D. chrysanthemi & IFB0320 & 2011 & $\mathrm{Na}$ & $\mathrm{Na}$ & $0.3( \pm 0.09)$ & 4 \\
\hline 27 & D. chrysanthemi & IFB0321 & 2011 & $\mathrm{Na}$ & $\mathrm{Na}$ & $\ldots$ & 4 \\
\hline 28 & D. chrysanthemi & IFB0336 & 2011 & $\mathrm{Na}$ & $\mathrm{Na}$ & $\ldots$ & 48 \\
\hline \multirow[t]{2}{*}{29} & D. zeae & IFB0189 & 2010 & $\mathrm{Na}$ & $\mathrm{Na}$ & $1.56( \pm 0.27)$ & 7 \\
\hline & & & & & & \multicolumn{2}{|c|}{ (continued on next page) } \\
\hline
\end{tabular}

a Dickeya isolates from potato plants (Potato) or water.

b IFB0099 (101A/9/2005, IPO2276) was isolated by Sławiak et al. (2009a,b) and IFB0158 was isolated by Potrykus et al. (2014a). All others strains were isolated in the current study and some of them were deposited at BCCM/LMG: D. chrysanthemi IFB0289 (LMG28830), IFB0320 (LMG28831); D. dianthicola IFB0157 (LMG28825), IFB0485 (LMG28834); D. solani IFB0168 (LMG28827); D. zeae IFB0189 (LMG28828), IFB0280 (LMG28829), IFB0329 (LMG28832), IFB0334 (LMG28833).

c Na indicates not applicable to water isolates.

d Values are the means \pm standard error $(n=6)$ of the fresh mass (grams) of macerated tissue per tuber in the potato maceration assay; $\ldots$ indicates that the assay was not performed for this isolate.

e Numbers indicate pulsed-field gel electrophoresis (PFGE) profiles obtained for the reference strains and isolates from water and potato plants isolated in Poland and other European countries. 
In 2010, samples were collected from the same location twice each year. Beginning in 2011, samples collected in August to September (the second sampling in the year) were collected only from the four southern voivodeships. The samples originated from rivers, lakes, ponds, drainage ditches, and other types of surface water located near potato plantations. Water samples were also collected from potatoprocessing plants (samples were untreated) and from a maximum of 10 sewage plants (samples were untreated) in each region. The water samples were stored in the dark at room temperature for approximately 1 to 2 weeks before they were transferred to our laboratory.

Bacteria detection and isolation from potato plant and water samples. Because new information concerning bacterial detection and taxonomy became available during the 5 years of monitoring, the methods differed depending on the year. In 2009, we isolated pectinolytic bacteria from homogenized potato plant tissue on CVP medium, as described by Potrykus et al. (2014b), and approximately 1,000 pectinolytic isolates were tested with ADE1 and ADE2 PCR primers specific for Dickeya spp. (Nassar et al. 1996). Beginning in 2010, the procedure proposed by Potrykus et al. (2014b) was followed. Briefly, total genomic DNA was obtained from the potato samples. The DNA was subjected to multiplex polymerase chain reaction (PCR) targeting Dickeya spp., Pectobacterium atrosepticum, and $P$. carotovorum subsp. carotovorum $+P$. wasabiae in one reaction. If Dickeya spp. DNA was detected in the sample, we attempted bacterial isolation. Each year, samples of homogenized potato tissues and Dickeya isolates were frozen in $40 \%$ glycerol and stored at $-80^{\circ} \mathrm{C}$. To standardize procedures, the frozen homogenates from 2009 were reanalyzed by subjecting total DNA to the multiplex PCR.
For water samples, pectinolytic bacteria were isolated on CVP medium and subjected to PCR (Nassar et al. 1996) or multiplex PCR (Potrykus et al. 2014b). In all, 10 water samples (5 ml each) were combined and vigorously mixed, and the pooled sample was placed in a $50-\mathrm{ml}$ Falcon test tube. Then, $0.2 \mathrm{ml}$ of each pooled sample was spread on CVP and incubated at 28 and $37^{\circ} \mathrm{C}$. After 48 to $72 \mathrm{~h}$, the CVP plates were assessed for the presence of pit-forming bacteria (i.e., pectinolytic bacteria). If a pooled sample was positive for pectinolytic bacterial colonies, the individual water samples that were used to obtain the pooled sample were spread on CVP medium, and pectinolytic bacteria were isolated. The pectinolytic isolates that were identified as Dickeya spp. by PCR (Nassar et al. 1996) or multiplex PCR (Potrykus et al. 2014b) were purified on CVP and LA media, frozen in $40 \%$ glycerol, and stored at $-80^{\circ} \mathrm{C}$.

Characterization and phylogenetic analysis of Dickeya isolates. Pectinolytic Dickeya isolates obtained from symptomatic potato samples or from waterways were subjected to genome-wide analysis by DNA restriction enzyme digestion with $\mathrm{XbaI}$ (restriction fragment length polymorphism [RFLP]) and pulsed-field gel electrophoresis (PFGE) and were grouped according to their PFGE profiles (Lee et al. 2006; Degefu et al. 2013). Assignment of strains with similar PFGE patterns to individual Dickeya spp. was based on sequencing of the dnaX housekeeping gene (Sławiak et al. 2009b) and, in some cases, on sequencing of recA (Parkinson et al. 2009; Waleron et al. 2002), gyrA (van der Wolf et al. 2014), and rpoS (Waleron et al. 2002). The amplicons were purified with a Clean-Up kit (A\&A Biotechnology) and sequenced from both ends by Genomed. Phylogenetic analysis was based on dnaX gene sequences that were

Table 2. (continued from preceding page)

\begin{tabular}{|c|c|c|c|c|c|c|c|}
\hline Isolate $^{a}$ & Species & IFB numberb & Year of isolation & Potato cultivar ${ }^{\mathrm{c}}$ & Plant part ${ }^{\mathrm{c}}$ & Potato maceration assay ${ }^{d}$ & PFGE profile $e^{e}$ \\
\hline 30 & D. zeae & IFB0190 & 2010 & $\mathrm{Na}$ & $\mathrm{Na}$ & $\ldots$ & 7 \\
\hline 31 & D. zeae & IFB0191 & 2010 & $\mathrm{Na}$ & $\mathrm{Na}$ & $\ldots$ & 37 \\
\hline 32 & D. zeae & IFB0192 & 2010 & $\mathrm{Na}$ & $\mathrm{Na}$ & $2.84( \pm 0.47)$ & 7 \\
\hline 33 & D. zeae & IFB0193 & 2010 & $\mathrm{Na}$ & $\mathrm{Na}$ & $\ldots$ & 7 \\
\hline 34 & D. zeae & IFB0194 & 2010 & $\mathrm{Na}$ & $\mathrm{Na}$ & $\ldots$ & 38 \\
\hline 35 & D. zeae & IFB0197 & 2010 & $\mathrm{Na}$ & $\mathrm{Na}$ & $\ldots$ & 8 \\
\hline 36 & D. zeae & IFB0280 & 2011 & $\mathrm{Na}$ & $\mathrm{Na}$ & $3.41( \pm 0.41)$ & 9 \\
\hline 37 & D. zeae & IFB0281 & 2011 & $\mathrm{Na}$ & $\mathrm{Na}$ & $\ldots$ & 9 \\
\hline 38 & D. zeae & IFB0282 & 2011 & $\mathrm{Na}$ & $\mathrm{Na}$ & $\ldots$ & 9 \\
\hline 39 & D. zeae & IFB0285 & 2011 & $\mathrm{Na}$ & $\mathrm{Na}$ & $\ldots$ & 12 \\
\hline 40 & D. zeae & IFB0286 & 2011 & $\mathrm{Na}$ & $\mathrm{Na}$ & $\ldots$ & 12 \\
\hline 41 & D. zeae & IFB0290 & 2011 & $\mathrm{Na}$ & $\mathrm{Na}$ & $\ldots$ & 6 \\
\hline 42 & D. zeae & IFB0291 & 2011 & $\mathrm{Na}$ & $\mathrm{Na}$ & $\ldots$ & 6 \\
\hline 43 & D. zeae & IFB0292 & 2011 & $\mathrm{Na}$ & $\mathrm{Na}$ & $\ldots$ & 5 \\
\hline 44 & D. zeae & IFB0293 & 2011 & $\mathrm{Na}$ & $\mathrm{Na}$ & $0.63( \pm 0.33)$ & 41 \\
\hline 45 & D. zeae & IFB0294 & 2011 & $\mathrm{Na}$ & $\mathrm{Na}$ & $\ldots$ & 5 \\
\hline 46 & D. zeae & IFB0295 & 2011 & $\mathrm{Na}$ & $\mathrm{Na}$ & $\ldots$ & 5 \\
\hline 47 & D. zeae & IFB0319 & 2011 & $\mathrm{Na}$ & $\mathrm{Na}$ & $\ldots$ & 42 \\
\hline 48 & D. zeae & IFB0322 & 2011 & $\mathrm{Na}$ & $\mathrm{Na}$ & $\ldots$ & 10 \\
\hline 49 & D. zeae & IFB0323 & 2011 & $\mathrm{Na}$ & $\mathrm{Na}$ & $\ldots$ & 10 \\
\hline 50 & D. zeae & IFB0324 & 2011 & $\mathrm{Na}$ & $\mathrm{Na}$ & $0.88( \pm 0.37)$ & 13 \\
\hline 51 & D. zeae & IFB0325 & 2011 & $\mathrm{Na}$ & $\mathrm{Na}$ & $\ldots$ & 13 \\
\hline 52 & D. zeae & IFB0326 & 2011 & $\mathrm{Na}$ & $\mathrm{Na}$ & $\ldots$ & 8 \\
\hline 53 & D. zeae & IFB0327 & 2011 & $\mathrm{Na}$ & $\mathrm{Na}$ & $\ldots$ & 11 \\
\hline 54 & D. zeae & IFB0328 & 2011 & $\mathrm{Na}$ & $\mathrm{Na}$ & $\ldots$ & 11 \\
\hline 55 & D. zeae & IFB0329 & 2011 & $\mathrm{Na}$ & $\mathrm{Na}$ & $0.23( \pm 0.23)$ & 14 \\
\hline 56 & D. zeae & IFB0330 & 2011 & $\mathrm{Na}$ & $\mathrm{Na}$ & $\ldots$ & 14 \\
\hline 57 & D. zeae & IFB0331 & 2011 & $\mathrm{Na}$ & $\mathrm{Na}$ & $\ldots$ & 43 \\
\hline 58 & D. zeae & IFB0332 & 2011 & $\mathrm{Na}$ & $\mathrm{Na}$ & $\ldots$ & 44 \\
\hline 59 & D. zeae & IFB0333 & 2011 & $\mathrm{Na}$ & $\mathrm{Na}$ & $\ldots$ & 45 \\
\hline 60 & D. zeae & IFB0334 & 2011 & $\mathrm{Na}$ & $\mathrm{Na}$ & $3.83( \pm 0.48)$ & 46 \\
\hline 61 & D. zeae & IFB0335 & 2011 & $\mathrm{Na}$ & $\mathrm{Na}$ & $\ldots$ & 47 \\
\hline 62 & D. zeae & IFB0338 & 2011 & $\mathrm{Na}$ & $\mathrm{Na}$ & $\ldots$ & 5 \\
\hline 63 & D. zeae & IFB0339 & 2011 & $\mathrm{Na}$ & $\mathrm{Na}$ & $\begin{array}{l}\cdots \\
\ldots\end{array}$ & 5 \\
\hline 64 & D. zeae & IFB0488 & 2013 & $\mathrm{Na}$ & $\mathrm{Na}$ & $1.21( \pm 0.4)$ & 49 \\
\hline 65 & D. zeae & IFB0489 & 2013 & $\mathrm{Na}$ & $\mathrm{Na}$ & $1.72( \pm 0.5)$ & 16 \\
\hline 66 & D. zeae & IFB0490 & 2013 & $\mathrm{Na}$ & $\mathrm{Na}$ & $2.95( \pm 0.31)$ & 50 \\
\hline
\end{tabular}


manually edited with Bioedit 7.2.5 (Hall 1999). The dnaX sequences of $P$. atrosepticum IPO980, $P$. wasabiae SCRI3193, and $P$. carotovorum subsp. carotovorum 3733 were used as outgroups. The tree was generated with the maximum-likelihood method using Phylogeny.lirmm.fr (Dereeper et al. 2008) and was edited with TreeGraph 2 (Stöver and Müller 2010). dnaX sequences of Dickeya spp. reference strains were obtained from GenBank. The tree was submitted to TreeBase Database (www.treebase.org) with the reference number 17463.

Potato tuber maceration assay. 'Lord' potato tubers were inoculated with pectinolytic Dickeya isolates obtained from potato fields and water, as previously described (Hugouvieux-Cotte-Pattat et al. 2004). In brief, the potato tubers were washed in tap water and dried. Six to nine potato tubers, each containing one hole made with a sterile pipette tip, were inoculated with $5 \mu \mathrm{l}$ of every bacterial strain suspension $\left(5 \times 10^{6} \mathrm{CFU}\right)$. Inoculated holes were then covered with mineral oil to provide anaerobic conditions. After $48 \mathrm{~h}$ at $28^{\circ} \mathrm{C}$, the rotted potato tissue was removed and weighed without drying. The experiment was performed twice.

The weather conditions. Daily rainfall and temperature records during the years of monitoring in Poland were obtained from the Institute of Meteorology and Water Management, National Research Institute, Warsaw, Poland, as a result of standard procedure executed by the national hydrological and meteorological service. The daily rainfall and temperature records were used for monthly average sum of rainfall and monthly average temperature calculations for the territory of Poland and are presented in Supplementary Figure S1.

Data analysis. The ability of Dickeya isolates to macerate potato tissue was compared by analysis of variance followed by Tukey's posthoc test. Statistica 10.0 StatSoft Polska was used for all statistical analyses. Data are presented as means \pm standard error, and significance was determined at $P<0.05$.

\section{Results}

Detection of Dickeya spp. Pectinolytic bacteria were detected in $65 \%$ of the potato samples. The percentage of potato samples in which pectinolytic bacteria were identified by multiplex PCR was $63 \%$ in $2009,71 \%$ in $2010,82 \%$ in 2011 , and $42 \%$ in 2013 . The percentage of potato samples in which Dickeya spp. were detected by multiplex PCR was $4.24 \%$ in $2009,1.39 \%$ in $2010,12.11 \%$ in 2011, and $2.54 \%$ in 2013. Over the 4 years of sampling, Dickeya spp. were detected in 39 (35 stem and 4 tuber samples) of 768 samples by multiplex PCR. Dickeya spp. alone were detected in 22 samples and Dickeya spp. along with Pectobacterium spp. were detected in 17 samples. Of the 39 potato samples positive for Dickeya spp. by the multiplex PCR assay, viable cells were isolated from 18 stem samples and 1 tuber sample (Table 2). From 1 to 10 Dickeya isolates from each potato sample were obtained. Voivodeships in which Dickeya spp. were identified on potato plants differed from year to year (Fig. 1). Over the 4 years of sampling, Dickeya spp. were detected in 11 of the 14 voivodeships that were surveyed.

Viable cells of pectinolytic Dickeya spp. were isolated from 28 of the 7,902 water samples (Table 2). The pectinolytic bacteria were isolated from 6 water samples in 2010, 19 in 2011, 0 in 2012, and 3 in 2013. In total, 46 Dickeya strains were isolated from 28 water samples. The geographical distribution of Dickeya spp. in water samples differed among years but Dickeya spp. were detected in most of the surveyed voivodeships (Fig. 1B).

Poland has a humid continental climate (a transient temperate climate), and weather conditions are likely to affect the development of blackleg or soft rot in the field. We examined the influence of weather conditions on the occurrence of Dickeya spp. in the potato fields. Using multiplex PCR, we detected Dickeya spp. in $12.11 \%$ of the samples in 2011 but in only $1.39 \%$ of samples in 2010 . The average temperature in 2011 was the highest $\left(8.7^{\circ} \mathrm{C}\right)$ in the investigated period whereas it was the lowest $\left(7.3^{\circ} \mathrm{C}\right)$ in 2010 . The average monthly rainfall was lower in $2011(760 \mathrm{~mm})$ than in $2010(1,120 \mathrm{~mm})$ but the amount of rainfall was 1.5-fold higher in July 2011 than in July 2010.

Overall, the highest number of Dickeya isolates were obtained in 2011 from both potato and water samples (Fig. 1). In total, 19
Dickeya isolates from potato plants and 46 from water samples were subjected to characterization.

Dickeya isolates from potato plants were $D$. solani or D. dianthicola. We characterized Dickeya spp. isolated from 19 symptomatic potato plants (Table 2). RFLP-PFGE analysis was performed on all Dickeya isolates. In every case, profiles of strains derived from the same sample (the same plant) were identical (data not shown). For characterization of the Dickeya isolates, one representative isolate from each symptomatic plant was chosen. One of the first Polish strains of D. solani isolated in 2005 (IFB0099, $101 \mathrm{~A} / 9 / 2005$ ) was used as a reference and, all together, 20 isolates from potato were assessed. The Dickeya isolates predominantly originated from symptomatic potato stems; only one isolate (IFB0486) was obtained from rotten potato tuber. PFGE profiling indicated that the isolates from potato samples clustered into three groups (Fig. 2; Table 2). Seventeen D. solani isolates (including the isolate from 2005) had PFGE profiles that were identical to that of the reference strain D. solani IPO2222 (NCPPB4479 ${ }^{\mathrm{T}}$, IFB0123). One Dickeya isolate from 2009 (IFB0157) grouped together with the type strain of D. dianthicola (CFBP1200 ${ }^{\mathrm{T}}$, IFB0103). In addition, two Dickeya isolates from 2013 (IFB0485 and IFB0486) had identical profiles that differed from the profiles of the $D$. dianthicola CFBP $1200^{\mathrm{T}}$.

dnaX sequence data from 20 isolates were used to perform a phylogenetic analysis. The sequences of other genes were also used to identify isolates to species; $r e c A$ was sequenced for five isolates, $r p o S$ for three isolates, and gyrA for eight isolates. In the phylogenetic analysis based on dnaX sequences, all isolates previously identified by RFLP-PFGE analysis as $D$. solani grouped with the reference strains of this species (Fig. 3). dnaX sequences of D. dianthicola IFB0157, IFB0485, and IFB0486 were identical and grouped with the sequences of $D$. dianthicola $\mathrm{CFBP} 1200^{\mathrm{T}}$ even though the three isolates did not exhibit the same PFGE profile (Fig. 3). Altogether, we isolated 16 strains of $D$. solani that were identical both in RFLPPFGE and in sequences of $\operatorname{dnaX}, \operatorname{rec} A, \operatorname{rpoS}$, and gyrA; and three strains that were classified as $D$. dianthicola based on $d n a X$ sequence but that exhibited two different PFGE profiles. When all of the obtained sequences were compared with those in GenBank, all D. solani gene fragments were the same as in D. solani IPO2222, and the $D$. dianthicola fragments were the same as in D. dianthicola CFBP1200 ${ }^{\mathrm{T}}$.

In the potato tuber assay, the ability of $D$. solani isolates from 2005, 2009, 2010, 2011, and 2013 to macerate plant tissue was similar to that of the D. solani reference strain IPO2222 (Fig. 4A; Tables 1 and 2). Maceration ability was higher for the tested $D$. solani isolates than for the tested $D$. dianthicola isolates and was intermediate for the reference strain D. dianthicola CFBP $1200^{\mathrm{T}}$ (Fig. 4A).

Dickeya isolates from water sources are more diverse than those from potato plants. We obtained 46 pectinolytic Dickeya isolates from 28 water samples (Table 2). All 46 isolates were subjected to RFLP-PFGE analysis and $d n a X$ gene sequencing. Moreover, $r p o S$ was sequenced for four isolates and $r e c A$ was sequenced for seven isolates. For comparison of diversity, PFGE analysis and housekeeping gene sequencing were also performed for Dickeya spp. isolated from water sources in other European countries (Fig. 5; Table 1). We included two isolates from Scotland for which draft genome sequences are available in GenBank (MK16 and MK7), three other isolates from Scotland (River1-1, River2-1, and River3-1), four isolates from Finland (Dw0431, Dw0440, Dw054, and Dw0512), three isolates from England (RW117, RW157, and P7246), and one isolate from Spain (CITA A-3) (Table 1). These European strains were previously identified as $D$. aquatica, $D$. dadantii subsp. dieffenbachiae, D. solani, and D. zeae (Palacio-Bielsa et al. 2010; Parkinson et al. 2014; Pritchard et al. 2013a,c) (Toth and Saddler, personal communication).

The 46 Polish Dickeya isolates from water exhibited 26 different PFGE profiles. Only a few of the PFGE profiles were identical. The profiles of the Polish isolates were also different from the profiles of Dickeya spp. reference strains (Figs. 2 and 5; Tables 1 and 2).

In the phylogenetic analysis based on dnaX sequences, the Dickeya isolates from water sources formed two clades. The first clade contained seven isolates from three water samples collected in 
midwestern (IFB0283, IFB0284, IFB0287, IFB0288, and IFB0289) and southern (IFB0320 and IFB0321) Poland in 2011 (Fig. 3). Although this clade included $D$. chrysanthemi pv. chrysanthemi reference strain NCPPB $402^{\mathrm{T}}$ (IFB0055), PFGE profiles of these seven isolates differed from the one of reference strain NCPPB $402^{\mathrm{T}}$. PFGE profiles were identical for isolates IFB0287, IFB0288, IFB0320, and IFB0321 but were unique for the other three isolates in this clade. The second clade of Dickeya isolates from water consisted of 39 isolates (Table 2) that grouped with D. zeae reference strains (Fig. 3). Again, the PFGE profiles were diverse, and only the profile of IFB0489 was identical to that of D. zeae IPO3329. Although D. dianthicola and
D. solani were isolated from water in other European countries (Laurila et al. 2008, Toth et al. 2011), they were not isolated from water in the current study in Poland. D. aquatica also was not detected in this survey.

We also examined PFGE profiles of European Dickeya isolates from water. Each Finnish D. aquatica isolate exhibited a unique but similar PFGE profile (Fig. 5) but these isolates were identical in terms of dnaX sequence (Fig. 3). The profile for River1-1 from Scotland was identical to that of MK7 from Scotland (Fig. 5), and they grouped into one clade based on dnaX phylogeny (Fig. 3). Among the three isolates from England, the PFGE profiles of
A

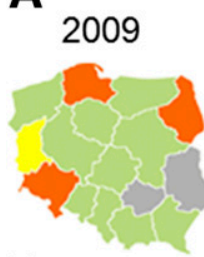

B

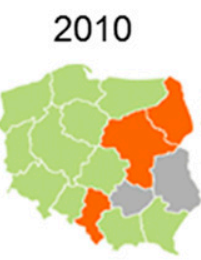

2011
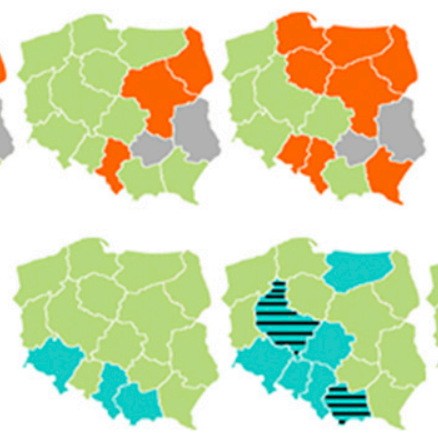

2012
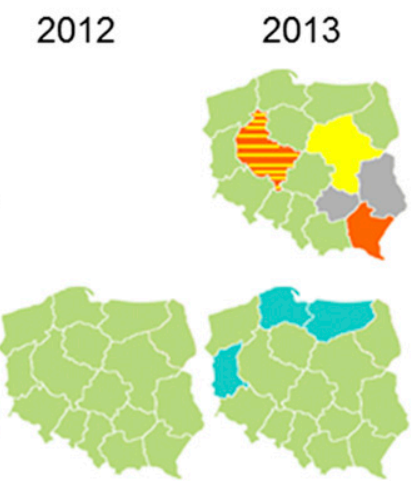

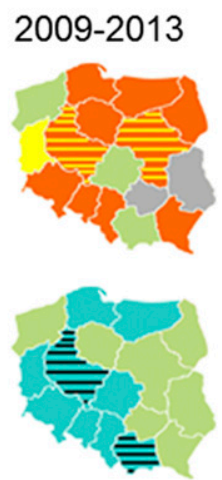

Fig. 1. Detection of Dickeya spp. in A, potato plants and B, water in Poland. Potato fields were sampled in 2009, 2010, 2011, and 2013. Water sources were sampled in 2010, 2011, 2012, and 2013. Regions from which inspectors did not provide any samples are indicated in gray. Listed colors indicate regions where the following Dickeya spp. were detected: orange $=$ Dickeya solani, yellow $=D$. dianthicola, orange/yellow $=$ both $D$. solani and $D$. dianthicola, blue $=D$. zeae, blue/black $=$ both $D$. zeae and $D$. chrysanthemi. Green color was implemented for regions where no Dickeya spp. were detected.
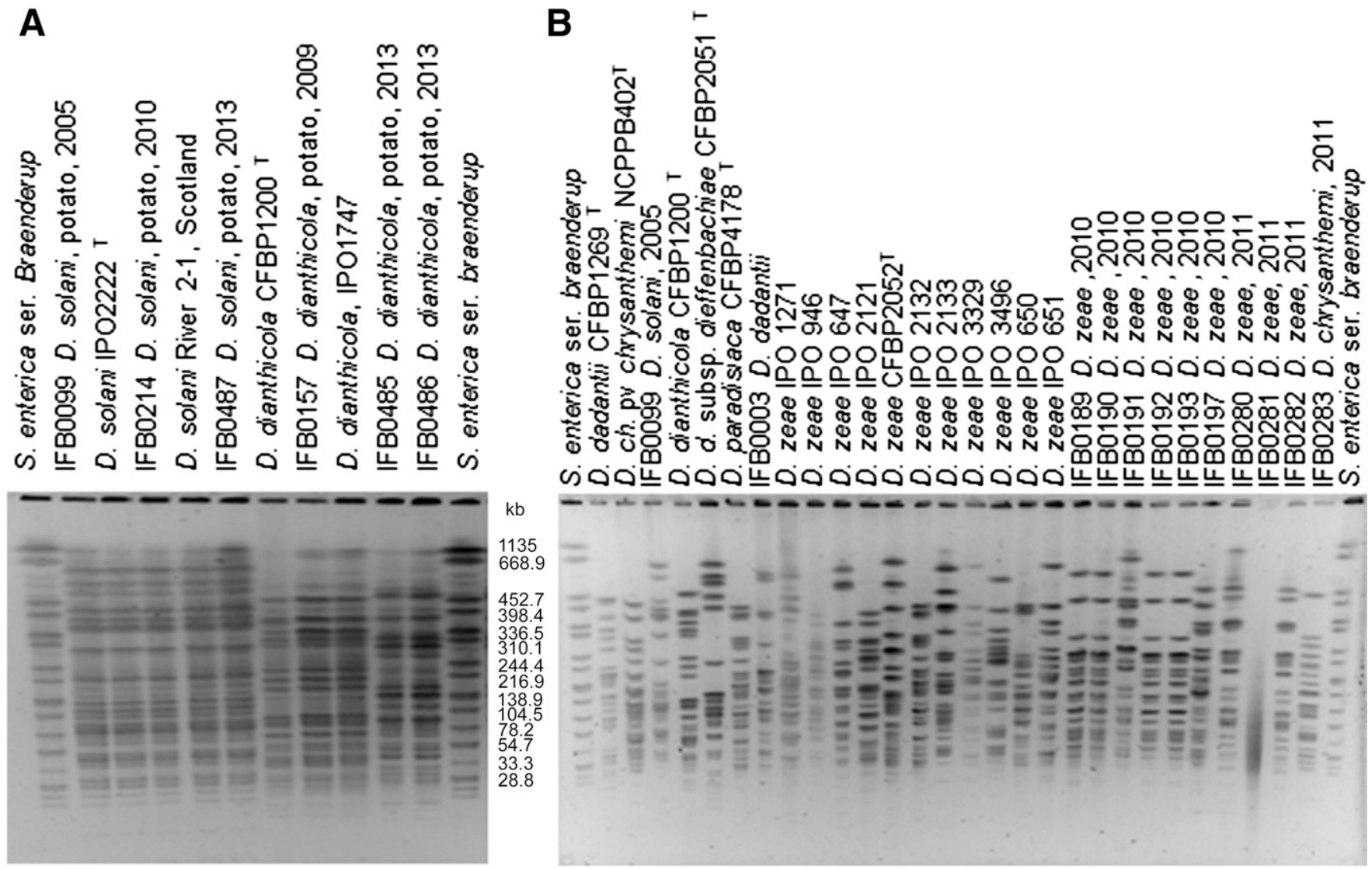

Fig. 2. Restriction fragment length polymorphism pulsed-field gel electrophoresis (RFLP-PFGE) analysis of Dickeya spp. genomic profiles. Investigated strains were isolated from A, potato and B, water samples in Poland. Reference strains of Dickeya spp. were included. A, Polish strains isolated from potato formed three groups: the first group belongs to Dickeya solani while the other two groups belong to $D$. dianthicola. B, PFGE profiles indicate the substantial diversity of isolates from water samples. The size marker is the genomic DNA of Salmonella enterica ser. branderup digested with Xbal. 
RW157 and P7246 were identical but differed from that of RW117 (data not shown). Overall, the genetic diversity of Dickeya spp. from water sources was high among Polish and European isolates (Figs. 2 and 5).
The potato maceration assay was performed with 11 representative isolates from water that differed in PFGE profile and origin. For comparison, the assay included the following reference strains: D. chrysanthemi pv. chrysanthemi NCPPB $402^{\mathrm{T}}$ (IFB0055), D. zeae

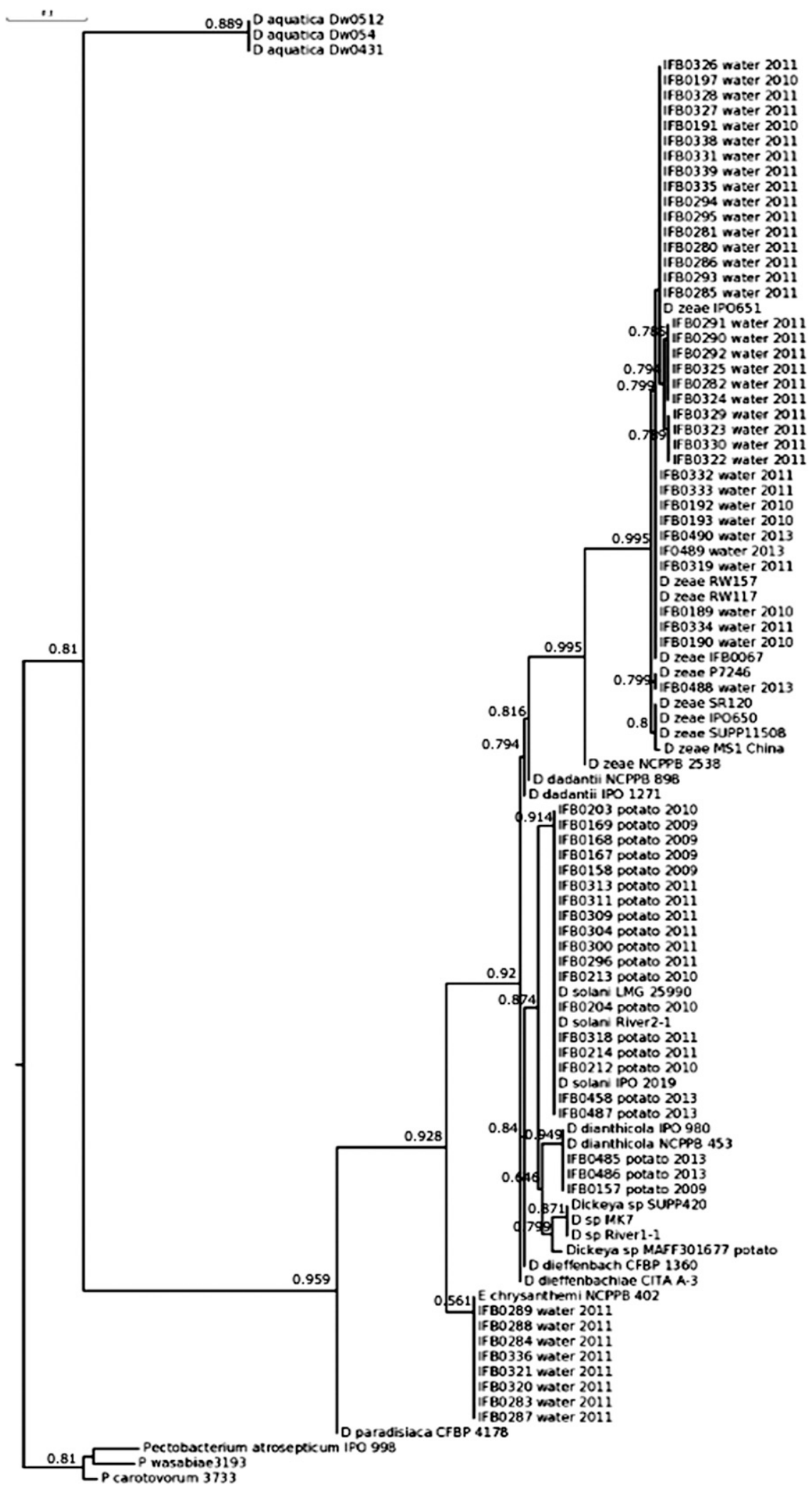

Fig. 3. Phylogenetic analysis based on $d n a X$ sequences of 20 Dickeya isolates from potato and 46 from water in Poland. The reference strains of Dickeya spp. and water isolates from other European countries are included in the analysis. The $d n a X$ sequences of Pectobacterium atrosepticum IPO980, $P$. wasabiae SCRI3193, and $P$. carotovorum subsp. carotovorum 3733 were used as an outgroup. Bootstrap values are shown at the nodes. The tree is drawn to scale, with branch length reflecting evolutionary distance between strains. The tree was generated by the maximum-likelihood method with Phylogeny.lirmm.fr (Dereeper et al. 2008) and was edited with TreeGraph (Stöver and Müller 2010). IFB = the collection of Intercollegiate Faculty of Biotechnology University of Gdansk and Medical University of Gdansk, Gdansk, Poland; IPO = the collection of Plant Research International, Wageningen, The Netherlands. 
phylotype II CFBP2052 ${ }^{\mathrm{T}}$ (IFB0119), and CFBP1278 (IFB0110). The Polish $D$. zeae isolates from water were more virulent than the reference strains NCPPB $402^{\mathrm{T}}$ and CFBP2052 ${ }^{\mathrm{T}}$ (Fig. 4B). However, the maceration ability of Polish $D$. chrysanthemi strain IFB0320 was lower than that of $D$. zeae strains and was similar to that of D. chrysanthemi pv. chrysanthemi $\mathrm{NCPPB} 402^{\mathrm{T}}$ (Fig. 4B; Tables 1 and 2). Interestingly, the diversity evident in the PFGE profiles was also evident in the potato maceration assay (Tables 1 and 2).

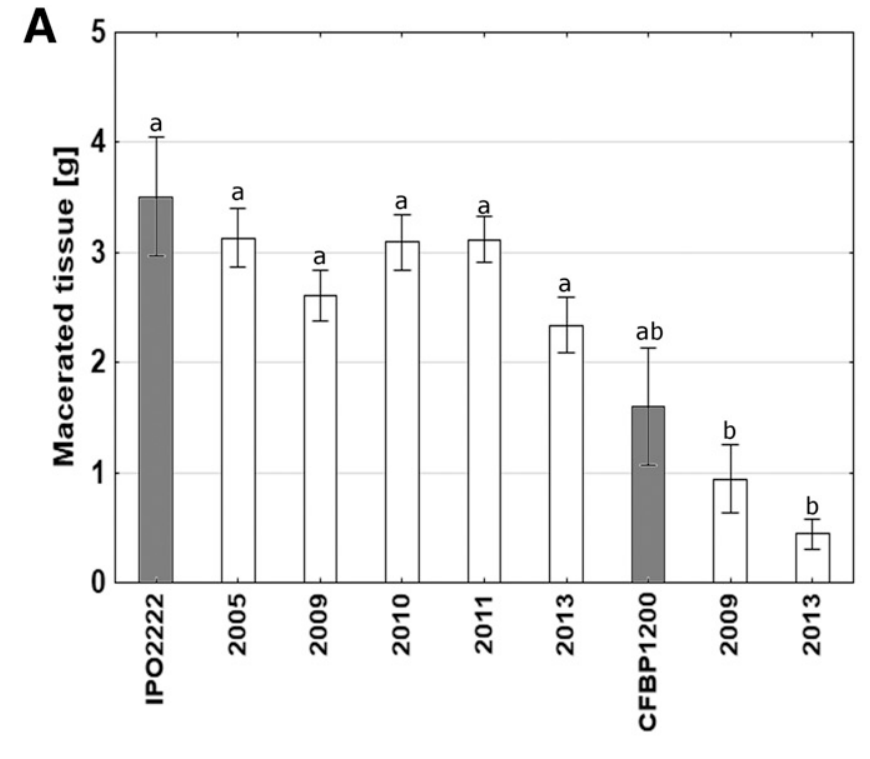

D. solani

\section{D. dianthicola}

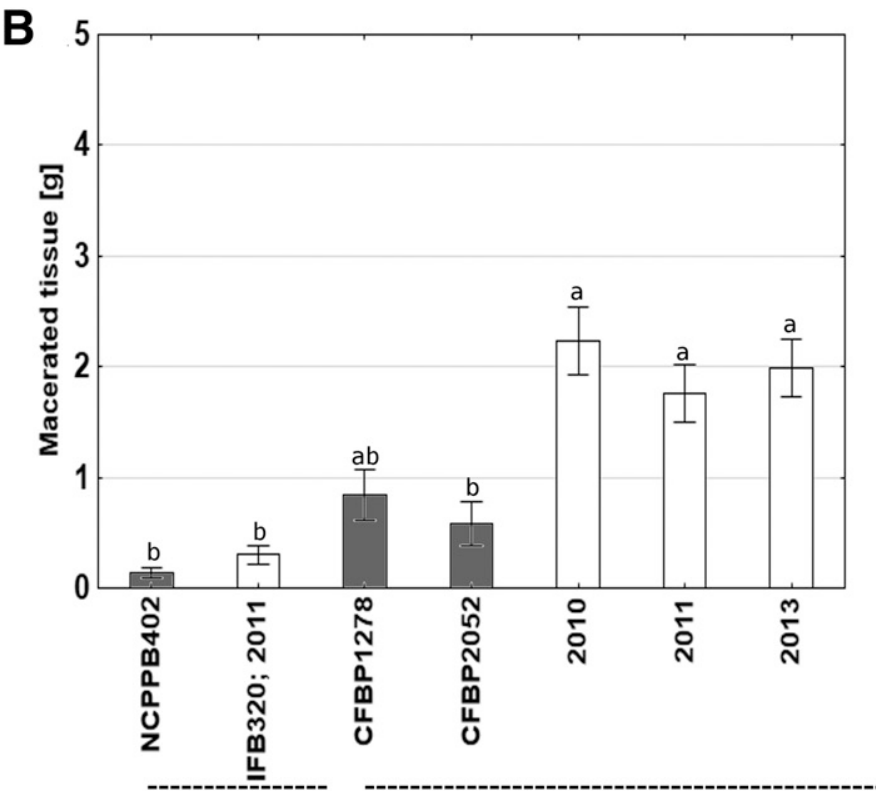

D. chrysanthemi

D. zeae

Fig. 4. Virulence of Dickeya isolates from $\mathbf{A}$, potato and $\mathbf{B}$, water as indicated by a potato tuber maceration assay. Reference strains are indicated by gray bars. For statistical analysis, isolates were grouped by year and species for potato isolates $(F=7.15)$ and for water isolates $(F=8.42)$. Effect of group (species-year) was tested with an analysis of variance, and means were compared by Tukey's posthoc test. Values are means \pm standard error $(n=6)$. In each panel, means with the same letter are not significantly different $(P>0.05) . \mathrm{NCPPB}_{402}{ }^{\top}=D$. chrysanthemi pv. chrysanthemi, CFBP1200 $=$ D. dianthicola, IPO2222 = D. solani, CFBP1278 $=D$. zeae, and CFBP2052 = D. zeae phylotype II.

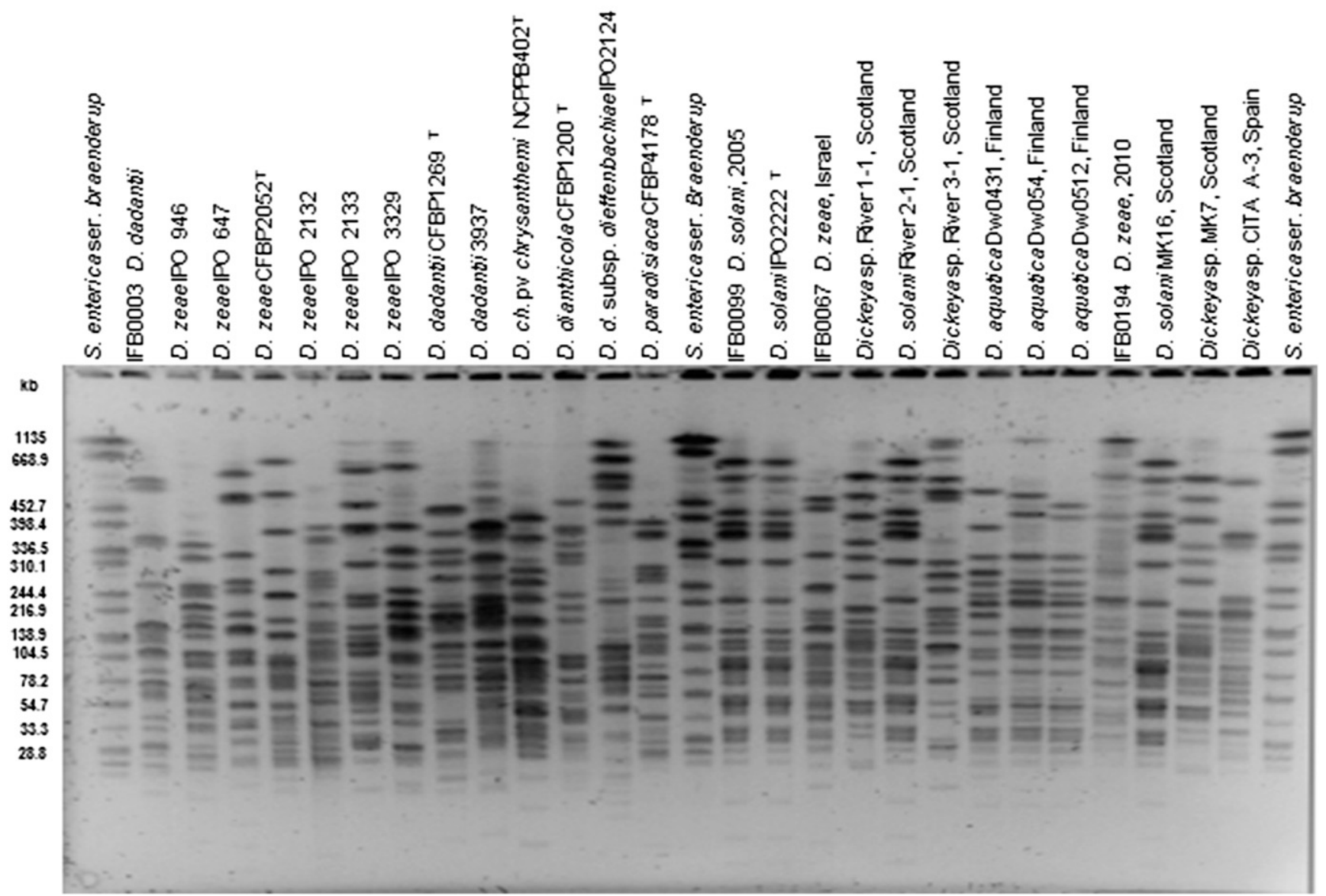

Fig. 5. Restriction fragment length polymorphism pulsed-field gel electrophoresis (RFLP-PFGE) profile analysis of water isolates from European countries (Scotland, Finland, Israel, and Spain) other than Poland. Reference strains of Dickeya spp. are included. The size marker used is the genomic DNA of Salmonella enterica ser. branderup digested with Xbal. 
The quantity of macerated tissue was 16 times greater for the most pathogenic D. zeae strain (IFB0334) than for the least pathogenic D. zeae strain (IFB0329) (Table 2).

\section{Discussion}

Bacteria belonging to the genus Dickeya cause blackleg and soft rot on many plants and are major problems in potato production (Czajkowski et al. 2011; Toth et al. 2011). We performed a 4-year survey of Dickeya spp. in potato seed plantations and waterways and other water sources in Poland. We detected Dickeya spp. in $39(5 \%)$ of the 786 potato plant samples and in $28(0.4 \%)$ of the 7,902 water samples.

Potato samples were analyzed as described by Potrykus et al. (2014b). Unfortunately, from 20 of the 39 potato plant samples in which Dickeya spp. DNA was detected, viable bacterial cells were not isolated. We suspect that the Dickeya spp. in the potato tissue did not survive transportation to our laboratory because of summer heat and rot caused by other bacteria or fungi. Another reason for the failure to isolate Dickeya spp. from PCR-positive samples could be coinfection with Pectobacterium spp. In 10 of 19 potato samples, extensive growth of Pectobacterium spp. on CVP plates interfered with the isolation of Dickeya spp.

Several studies of Dickeya spp. have been conducted in Europe over the last 10 years. In Spain, Dickeya spp. were detected in irrigation water and in potato and onion tissue (Palacio-Bielsa et al. 2010). In Finland, potato samples collected in 2004 and 2005 included 85 symptomatic stems and 23 rotten tubers (Laurila et al. 2008). Pectinolytic Dickeya spp. were isolated from $75 \%$ of symptomatic potato stems and $91 \%$ of symptomatic potato tubers. Strains belonging to Dickeya spp. were found in eight potato samples (Laurila et al. 2008). Dickeya spp. were also detected in seed potato tuber plantations in the High Grade zone in Finland (Degefu et al. 2013). In 2011 and 2012, D. solani was detected in symptomatic potato samples in The Netherlands, Denmark, Norway, Switzerland, Germany, and Czech Republic (EraNet Euphresco Report; J. van der Wolf and M. Bergsma Vlami, personal communication). Our findings indicate that Dickeya spp. are constantly present in Polish seed potato plantations, although the number of infected potato plants is low. We obtained 16 isolates of $D$. solani and 3 of $D$. dianthicola from potato samples. We did not isolate $D$. solani and $D$. dianthicola from the same potato plant, as reported in The Netherlands (R. Czajkowski, personal communication). However, we detected Dickeya spp. and Pectobacterium spp. in the same potato plant.

We also detected Dickeya spp. in water samples from Poland. Two Dickeya spp. were isolated from Polish water samples: D. zeae and D. chrysanthemi. The presence of Dickeya spp. in water samples was also investigated in The Netherlands and England, where both $D$. zeae and D. solani strains were isolated; however, D. solani was isolated sporadically, while D. zeae was more abundant (EraNet Euphresco Report; J. van der Wolf and M. Bergsma Vlami, personal communication). D. dianthicola and $D$. solani have been isolated from water samples in other European countries (Laurila et al. 2008, Toth et al. 2011); however, these two species were not detected in Polish water samples in the current study. Moreover, we did not detect $D$. aquatica, which was recently detected in water samples in Finland and Scotland (Parkinson et al. 2014).

Overall, we obtained and characterized 19 Dickeya isolates from potato plants and 46 from water samples. PFGE profiling proved to be an efficient and reproducible method for determining isolate diversity. PFGE profiles for Dickeya isolates from the same potato plant were always identical. Also, all $D$. solani PFGE profiles were the same, suggesting homogeneity among this species regardless of isolate origin. In contrast to low biodiversity of the Dickeya strains isolated from potato (only three PFGE profiles: one for $D$. solani and two for D. dianthicola), high diversity was observed for Dickeya strains isolated from water (26 PFGE profiles:4 for D. chrysantemi and 22 for D. zeae). Most water isolates were obtained from southern Poland, which is frequently flooded and is the main region for maize cultivation. According to phylogeny based on dnaX, most of our water isolates were $D$. zeae. It would be useful to determine whether $D$. zeae can be found in maize fields in Poland. The dnaX-based phylogeny of the isolates enabled us to assign them to species, and such assignments were confirmed by analysis of $r e c A$ sequences (data not shown).

Regarding the ability to macerate potato tissue under laboratory conditions, the Dickeya isolates from potato formed two groups: $D$. solani with high virulence and $D$. dianthicola with low virulence. Under our experimental conditions, the $D$. dianthicola isolates were even less virulent than $D$. zeae water isolates. $D$. zeae isolates were more virulent than the reference strain of this species, suggesting that D. zeae represents a potential threat to potato production in Poland. However, the virulence of these isolates should be verified under greenhouse and field conditions.

Examination of the influence of weather conditions on the occurrence of Dickeya spp. in the potato fields indicated that the highest number of $D$. solani strains was detected in 2011 , when the yearly average rainfall was the lowest and the yearly average temperature was the highest in comparison with 2009, 2010, and 2013. Our findings agree with Degefu et al. (2013), who suggested that the prevalence of Dickeya spp. is higher if the summer is hot and dry.

In summary, this is the first long-term, large-scale survey for Dickeya spp. in seed potato fields and water sources in Poland, which occupies a large portion of the temperate region of Central Europe. Only $D$. solani and $D$. dianthicola were isolated from symptomatic potato, and only D. zeae and $D$. chrysanthemi were isolated from water sources. Genetic diversity of Dickeya strains was low for potato isolates but very high for water isolates. The diversity in PFGE profiles of $D$. zeae strains matched their diversity in the virulence measured by the ability to macerate potato tissue. Polish $D$. solani strains indicated significantly higher potato maceration ability than $D$. zeae strains, and very high genetic homogeneity.

\section{Acknowledgments}

We thank A. Binek for the laboratory work. This work was supported by ESF within the framework of the HCOP, Action 4.1.2, LiSMIDoS, and National Science Center DEC-2013/08/T/NZ9/01020. It was also supported by grants from the National Science Center NSC 732/B/P01/2011/41, 2011-2014-05-26, and 2013/08/M/NZ9/00974 and POTPAT (Polish Norwegian Research Collaboration Pol-Nor/202448/28/2013).

\section{Literature Cited}

Brady, C. L., Cleenwerck, I., Denman, S., Venter, S. N., Rodríguez-Palenzuela, P., Coutinho, T. A., and De Vos, P. 2012. Proposal to reclassify Brenneria quercina (Hildebrand \& Schroth 1967) Hauben et al. 1999 into a novel genus, Lonsdalea gen. nov., as Lonsdalea quercina comb. nov., descriptions of Lonsdalea quercina subsp. quercina comb. nov., Lonsdalea quercina subsp. iberica subsp. nov. and Lonsdalea quercina subsp. britannica subsp. nov., emendation of the description of the genus Brenneria, reclassification of Dickeya dieffenbachiae as Dickeya dadantii subsp. dieffenbachiae comb. nov., and emendation of the description of Dickeya dadantii. Int. J. Syst. Evol. Microbiol. 62:1592-1602.

Czajkowski, R., Pérombelon, M. C. M., van Veen, J. A., and van der Wolf, J. M. 2011. Control of blackleg and tuber soft rot of potato caused by Pectobacterium and Dickeya species: A review. Plant Pathol. 60:999-1013.

Degefu, Y., Potrykus, M., Golanowska, M., Virtanen, E., and Lojkowska, E. 2013. A new clade of Dickeya spp. plays a major role in potato blackleg outbreaks in North Finland. Ann. Appl. Biol. 162:231-241.

Dereeper, A., Guignon, V., Blanc, G., Audic, S., Buffet, S., Chevenet, F., Dufayard, J. F., Guindon, S., Lefort, V., Lescot, M., Claverie, J. M., and Gascuel, O. 2008 Phylogeny.fr: Robust phylogenetic analysis for the non-specialist. Nucleic Acids Res. 36:W465-W469.

Elphinstone, J., and Toth, I. K. 2007. Erwinia chrysanthemi (Dickeya species.) The Facts. British Potato Council Publications. Online publication. http://potatoes. ahdb.org.uk/.

Hall, T. A. 1999. BioEdit: A user friendly biological sequence alignment editor and analysis program for Windows/p5/98/NT. Nucleic Acid Symp. Ser. 41:95-98.

Hugouvieux-Cotte-Pattat, N. 2004. The RhaS activator controls the Erwinia chrysanthemi 3937 genes rhiN, rhiT, and rhiE involved in rhamnogalacturonan catabolism. Mol. Microbiol. 51:1361-1374.

Hyman, L. J., Sullivan, L., Toth, I. K., and Pérombelon, M. C. M. 2001. Modified crystal violet pectate medium (CVP) based on a new polypectate source (Slendid) for the detection and isolation of soft rot erwinias. Potato Res. 44:265-270.

Kotoujansky, A., Lemattre, M., and Boistard, P. 1982. Utilization of a thermosensitive episome bearing transposon TnJO to isolate $\mathrm{Hfr}$ donor strains of Erwinia carotovora subsp. chrysanthemi. J. Bacteriol. 150:122-131.

Laurila, J., Ahola, V., Lehtinen, A., Joutsjoki, T., Hannukkala, A., Rahkonen, A., and Pirhonen, M. 2008. Characterization of Dickeya strains isolated from potato and river water samples in Finland. Eur. J. Plant Pathol. 122:213-225. 
Laurila, J., Hannukkala, A., Nykyr, J., Pasanen, M., Hélias, V., Garlant, L., and Pirhonen, M. 2010. Symptoms and yield reductions caused by Dickeya species strains isolated from potato and river water in Finland. Eur. J. Plant Pathol. 126:249-262.

Lee, Y. A., Chen, K. P., and Hsu, Y. W. 2006. Characterization of Erwinia chrysanthemi, the soft-rot pathogen of white-flowered calla lily, based on pathogenicity and PCR-RFLP and PFGE analyses. Plant Pathol. 55:530-536.

Ma, B., Hibbing, M. E., Kim, H. S., Reedy, R. M., Yedidia, I., Breuer, J., Breuer, J., Glasner, J. D., Perna, T., Kelman, A., and Charkowski, A. O. 2007. Host range and molecular phylogenies of the soft rot enterobacterial genera Pectobacterium and Dickeya. Phytopathology 97:1150-1163.

Mansfield, J., Genin, S., Magori, S., Citovky, V., Sriariyanum, M., Ronald, P., Dow, M., Verdier, V., Beer, S. V., Machado, M. A., Toth, I., Salmond, G., and Foster, G. D. 2012. Top 10 plant pathogenic bacteria in molecular plant pathology. Mol. Plant Pathol. 13:614-629.

Myung, I. S., Jeong, I. H., Moon, S. Y., Kim, W. G., Lee, S. W., Lee, Y. H., Lee, Y. K., Shim, H. S., and Ra, D. S. 2010. First report of bacterial stalk rot of sweet corn caused by Dickeya zeae in Korea. New Dis. Rep. 22:15.

Nassar, A., Darrassee, A., Lemattre, M., Kotoujansky, A., Dervin, C., Vedel, R., and Bertheau, Y. 1996. Characterization of Erwinia chrysanthemi by pectolytic isozyme polymorphism and restriction fragment length polymorphism analysis of PCR amplified fragment of pel genes. Appl. Environ. Microbiol. 62: 2228-2235.

Palacio-Bielsa, A., Mosquera, M. E. R., Álvarez, M. A. C., Rodríguez, I. M. B., López-Solanilla, E., and Rodríguez-Palenzuela, P. 2010. Phenotypic diversity, host range and molecular phylogeny of Dickeya isolates from Spain. Eur. J. Plant Pathol. 127:311-324.

Parkinson, N., DeVos, P., Pirhonen, M., and Elphinstone, J. 2014. Dickeya aquatica sp. nov., isolated from waterways. Int. J. Syst. Evol. Microbiol. 64: 2264-2266.

Parkinson, N., Stead, D., Bew, J., Heeney, J., Tsror (Lahkim), L., and Elphinstone, J. 2009. Dickeya species relatedness and clade structure determined by comparison of recA sequences. Int. J. Syst. Evol. Microbiol. 59:2388-2393.

Pérombelon, M. C. M. 2002. Potato diseases caused by soft rot erwinias: An overview of pathogenesis. Plant Pathol. 51:1-12.

Potrykus, M., Golanowska, M., Hugouvieux-Cotte-Pattat, N., and Lojkowska, E. 2014a. Regulators involved in Dickeya solani virulence, genetic conservation, and functional variability. Mol. Plant-Microbe Interact. 27:700-711.

Potrykus, M., Sledz, W., Golanowska, M., Sławiak, M., Binek, A., Motyka, A., Zoledowska, S., Czajkowski, R., and Lojkowska, E. 2014b. Simultaneous detection of major blackleg and soft rot bacterial pathogens in potato by multiplex polymerase chain reaction. Ann. Appl. Biol. 165:474-487.

Pritchard, L., Humphris, S., Baeyen, S., Maes, M., van Vaerenbergh, J., Elphinstone, J., Saddler, G. S., and Toth, I. K. 2013a. Draft genome sequences of four Dickeya dianthicola and four Dickeya solani strains. Genome Announc. 1:e00087-12.

Pritchard, L., Humphris, S., Saddler, G. S., Elphinstone, J. G., Pirhonen, M., and Toth, I. K. 2013b. Draft genome sequences of 17 isolates of the plant pathogenic bacterium Dickeya. Genome Announc. 1:e00978-13.

Pritchard, L., Humphris, S., Saddler, G. S., Parkinson, N. M., Bertrand, V., Elphinstone, J. G., and Toth, I. K. 2013c. Detection of phytopathogens of the genus Dickeya using a PCR primer prediction pipeline for draft bacterial genome sequences. Plant Pathol. 62:587-596.

$\mathrm{Pu}, \mathrm{X}$. M., Zhou, J. N., Lin, B. R., and Shen, H. F. 2012. First report of bacterial foot rot of rice caused by a Dickeya zeae in China. Plant Dis. 96:1818.

Sambrook, J., Fritsch, E. F., and Maniatis, T. 2000. Molecular Cloning: A Laboratory Manual, 3rd ed. Cold Spring Harbor Laboratory Press, Cold Spring Harbor, NY.

Samson, R., Legendre, J. B., Christen, R., Fischer-Le Saux, M., Achouak,W., and Gardan, L. 2005. Transfer of Pectobacterium chrysanthemi (Burkholder et al 1953) Brenner et al. 1973 and Brenneria paradisiaca to the genus Dickeya gen. nov. as Dickeya chrysanthemi comb. nov. and Dickeya paradisiaca comb. nov. and delineation of four novel species, Dickeya dadantii sp. nov., Dickeya dianthicola sp. nov., Dickeya dieffenbachiae sp. nov. and Dickeya zeae sp. nov. Int. J. Syst. Evol. Microbiol. 55:1415-1427.

Sarris, P. F., Trantas, E., Pagoulatou, M., Stavrou, D., Ververidis, F., and Goumas, D. E. 2011. First report of potato blackleg caused by biovar 3 Dickeya sp. (Pectobacterium chrysanthemi) in Greece. New Dis. Rep. 24:21.

Sławiak, M., Lojkowska, E., and van der Wolf, J. M. 2009a. First report of bacterial soft rot on potato caused by Dickeya sp. (syn. Erwinia chrysanthemi) in Poland. Plant Pathol. 58:794.

Sławiak, M., van Beckhoven, J. R. C. M., Speksnijider, A. G. C. L., Czajkowski, R., Grabe, G., and van der Wolf, J. M. 2009b. Biochemical and genetical analysis reveal a new clade of biovar 3 Dickeya spp. strains isolated from potato in Europe. Eur. J. Plant Pathol. 125:245-261.

Stöver, B. C., and Müller, K. F. 2010. TreeGraph 2: Combining and visualizing evidence from different phylogenetic analyses. BMC Bioinf. 11:7.

Suharjo, R., Sawada, H., and Takikawa, Y. 2014. Phylogenetic study of Japanese Dickeya spp. and development of new rapid identification methods using PCRRFLP. J. Gen. Plant Pathol. 80:237-254.

Toth, I. K., van der Wolf, J. M., Saddler, G., Lojkowska, E., Hélias, V., Pirhonen, M., Tsor, L., and Elphinstone, J. G. 2011. Dickeya species an emerging problem for potato production in Europe. Plant Pathol. 60:385-399.

Tsror (Lahkim), L., Erlich, O., Hazanovsky, M., Ben Daniel, B., Zig, U., and Lebiush, S. 2012. Detection of Dickeya spp. latent infection in potato seed tubers using PCR or ELISA and correlation with disease incidence in commercial field crops under hot-climate conditions. Plant Pathol. 61:161-168.

Tsror (Lahkim), L., Erlich, O., Lebiush, S., Hazanovsky, M., Zig, U., Sławiak, M. Grabe, G., van der Wolf, J. M., and van de Haar, J. J. 2009. Assessment of recent outbreaks of Dickeya sp.(syn. Erwinia chrysanthemi) slow wilt in potato crops in Israel. Eur. J. Plant Pathol. 123:311-320.

van der Wolf, J. M., Nijhuis, E. H., Kowalewska, M. J., Saddler, G. S., Parkinson, N., Elphinstone, J. G., Pritchard, L., Toth, I. K., Lojkowska, E., Potrykus, M., Waleron, M., de Vos, P., Cleenwerck, I., Pirhonen, M., Garlant, L., Helias, V., Pothier, J. F., Pflüger, V., Duffy, B., Tsror, L., and Manulis, S. 2014. Dickeya solani sp. nov., a pectinolytic plant pathogenic bacterium isolated from potato (Solanum tuberosum). Int. J. Syst. Evol. Microbiol. 64:768-774.

Waleron, M., Waleron, K., Podhajska, A. J., and Lojkowska, E. 2002. Genotyping of bacteria belonging to the former Erwinia genus by PCR-RFLP analysis of a recA gene fragment. Microbiology 148:583-595.

Zhang, J., Shen, H., Pu, X., Lin, B., and Hu, J. 2014. Identification of Dickeya zeae as a causal agent of bacterial soft rot in banana in China. Plant Dis. 98:436-442. 